\title{
Identifying Gross Spread Pattern In Indonesian Initial Public Offering Market
}

\author{
Nur Aida Arifah Tara ${ }^{1,2 *}$, Nada Kulendran ${ }^{1}$, Riccardo Natoli ${ }^{1}$ \\ ${ }^{1}$ College of Business \\ Victoria University \\ Melbourne, Australia \\ ${ }^{2}$ Faculty of Economics \\ University of Mataram, \\ Mataram, Indonesia \\ *nur.tara@live.vu.edu.au
}

\begin{abstract}
Underpricing, which is considered as the implicit cost of going public, is not the only cost faced by issuers. Another cost of going public is gross spread or underwriting discounts (i.e., explicit cost). This paper examines the gross spread in the Indonesian IPO market over the period of 2007 to 2016. The Indonesian underwriting market is characterized by different fee setting practices which focus more on the management fee to undertake marketing campaigns or road shows to obtain information and opinion from informed and potential investors prior to setting the offering price and IPO allocation. Using the relative frequency of the mode spread, it revealed that Indonesian gross spread did not show high clustering pattern even though gross spread level of $2 \%$ emerged as the common spread.
\end{abstract}

Keywords-Indonesian IPO market; gross spread; gross spread pattern

\section{INTRODUCTION}

For several years, underpricing has been the focus of research in Initial Public Offerings (IPOs). However, underpricing, which is considered as the implicit cost of going public, is not the only cost faced by issuers. Another cost of going public is gross spread or underwriting discounts (i.e, explicit cost).This is the difference between the offering price and the price paid by the underwriter to the issuers, or a percentage commission per share paid to the underwriters as compensation to cover expenses, management fees, commission and risk [1], [2].

The level of underwriter compensation in IPOs has drawn considerable attention from researchers. As Chen and Ritter (2000) reported, evidence of gross spread of firm-commitment IPOs in the U.S market was relatively high at $7 \%$ and this is higher than gross spread in other international markets. The U.S gross spread level was not only high, but also had a high frequency of gross spread at $7 \%$. This leads to the question of whether the cluster of gross spread is collusive. Subsequently, numerous studies have confirmed that clustering pattern is widespread, even in other markets with low gross spreads level, such Hong Kong, India, Malaysia, Singapore, Thailand, Belgium, France, Australia, and Taiwan [3], [4], [5].

Even though gross spread clustering is widespread in other markets, the Indonesian gross spread from 1986-1999 did not show evidence of a clustering pattern [4]. In this research, which studied the clustering pattern of the international market, found that Indonesian gross spread level was 3.6\%, which is higher than $2.4 \%$ for Asia Pacific countries, but relatively low compared to $4.3 \%$ for 27 countries. The gross spread level of $3.5 \%$ emerged as the most common gross spread, accounted for $27.3 \%$ of 11 Indonesian IPOs sample. However, this research only reported on 11 issuers, accounting for only $7 \%$ of IPOs in Indonesia. Thus, it needs further evaluation on the gross spread.

The overall objective of this research focuses on understanding the gross spread in Indonesia. In order to achieve the research objective, the aims of the study are to: 1) analyze the distribution of gross spread; and 2) identify gross spread patterns. The aims of the research are assessed by conducting evaluation on gross spread of IPO in the Indonesian market extending the work of [4] in several ways. First, it covered a larger sample. This examined the IPO gross spread and clustering patterns of gross spreads in 27 countries, including Indonesia. This study reported on 11 issuers, accounting for only $7 \%$ of IPOs in Indonesia. This paper used a large sample of 179 Indonesian IPOs or $86.47 \%$ of the total number of firms listed from 2007 to 2016. Second, this paper examined gross spread over several years and types of industries. Third, gross spread patterns of IPOs were identified using a larger sample than in the previous study.

The rest of paper is organized as follows. Section two shows the data, following with section three discussing the distribution of gross spread components. Section four presents the clustering pattern of gross spread. Section five presents discussions, and section six is the conclusion.

Acknowledgments: Australia Awards Scholarship (AAS) - DFAT, and

College of Business, Victoria University, Australia 


\section{THE DATA}

The study examined the gross spread of listed firms in the Indonesia Stock Exchange (IDX) during the period of January 2007 to December 2016. The chosen period of study started from 2007 because the information associated with gross spread has been available in the prospectuses of companies only since 2007. This was a result of BAPEPAM LK, the Financial Services Authority of Indonesia, which mandated that gross spread and offering price information had to be disclosed in a firm's prospectus. The initial sample was 206 IPOs in the Indonesia Stock Exchange (IDX) databases, and the final sample comprised 179 IPOs from nine industries. This sample represents $87 \%$ of the total firms listed in 2007 to 2016.

Table 1 shows the distribution of the total listed IPO and the sample according to year and industry. The number of IPOs listed per year varies, with 30 IPOs in 2013 as the highest number and 13 IPOs in 2009 as the lowest. The decrease number of IPOs was in 2009, due to the global financial crisis in 2008. The crisis caused the Indonesian Stock Exchange (IDX) composite index to significantly decrease to the lowest level. As a result, some firms postponed their IPO. For industry sample, trade, service and investment industry had the highest number of IPOs with a total of 48 IPOs during the sample period; meanwhile miscellaneous industry has the lowest IPOs with only 7 IPOs.

TABLE I. SAMPLE DISTRIBUTION BY YEAR AND INDUSTRY

\begin{tabular}{|l|c|c|c|}
\hline \multicolumn{2}{|l|}{$\begin{array}{c}\text { Total } \\
\text { IPO }\end{array}$} & $\begin{array}{c}\text { Sample } \\
\text { of IPOs }\end{array}$ & $\%$ \\
\hline Total & 206 & 179 & 87 \\
\hline \multicolumn{3}{|l|}{} & \\
\hline 2007 & 22 & 17 & 77 \\
\hline 2008 & 19 & 13 & 68 \\
\hline 2009 & 13 & 10 & 77 \\
\hline 2010 & 23 & 19 & 83 \\
\hline 2011 & 24 & 22 & 92 \\
\hline 2012 & 22 & 21 & 95 \\
\hline 2013 & 30 & 29 & 97 \\
\hline 2014 & 23 & 21 & 91 \\
\hline 2015 & 15 & 14 & 93 \\
\hline 2016 & 15 & 13 & 87 \\
\hline
\end{tabular}

\begin{tabular}{|c|c|c|c|}
\hline \multicolumn{4}{|l|}{ Panel B: Industry } \\
\hline Agriculture & 12 & 11 & 92 \\
\hline Mining & 23 & 23 & 100 \\
\hline Basic Industry and Chemicals & 12 & 10 & 83 \\
\hline Miscellaneous Industry & 7 & 7 & 100 \\
\hline Consumer Goods & 9 & 6 & 67 \\
\hline Property and Real Estate & 40 & 31 & 77 \\
\hline $\begin{array}{l}\text { Infrastructure, Utilities, and } \\
\text { Transportation }\end{array}$ & 23 & 22 & 96 \\
\hline Finance & 33 & 26 & 79 \\
\hline Trade, Service and Investment & 48 & 43 & 90 \\
\hline
\end{tabular}

Source : www.idx.co.id

\section{THE DISTRIBUTION OF GROSS SPREAD COMPONENTS}

Gross spread is partitioned into three components: management fee, underwriting fee and selling fee. Management fee enable underwriters to undertake marketing campaigns, assess market conditions, and organize road shows to obtain information and opinions from informed and potential investors prior to setting the offering price and IPO allocation [6]. Underwriting fee is used to compensate underwriters for making a capital commitment. Meanwhile, selling fee is used to compensate underwriters, who may be lead underwriters, co-managers, syndicate members, or nonunderwriters (selected dealers) in the selling group. Evaluating gross spread components are to determine the proportion of each component and the focus of explicit cost incurred by going public.

Table 2 shows the gross spread level, the level of gross spread component, and the proportion of each component by year. From the table, it can be seen that the mean gross spread of IPOs during the years 2007 to 2016 was $2.05 \%$, comprising $0.48 \%$ underwriting fee, $1.20 \%$ management fee, and $0.40 \%$ selling fee. The biggest proportion of gross spread components was the management fee (58\%), following by the underwriting fee $(23 \%)$ and the selling fee $(19 \%)$. It is apparent that the gross spread level decreased from $2.23 \%$ (2007) to 1.965 (2008), and remained stable for the following eight years from 2008 to 2015 . In 2016, the gross spread level increased to $2.36 \%$.

TABLE II. DISTRIBUTION OF GROSS SPREAD COMPONENTS BY YEAR

\begin{tabular}{|c|c|c|c|c|}
\hline & $\begin{array}{c}\text { Underwriting } \\
\text { Fee }\end{array}$ & $\begin{array}{c}\text { Management } \\
\text { Fee } \\
\end{array}$ & $\begin{array}{c}\text { Selling } \\
\text { Fee }\end{array}$ & $\begin{array}{c}\text { Gross } \\
\text { Spread }\end{array}$ \\
\hline \multicolumn{5}{|c|}{ Panel A: The Level of Components (\%) } \\
\hline 2007 & 0.66 & 1.42 & 0.52 & 2.23 \\
\hline 2008 & 0.54 & 1.04 & 0.38 & 1.96 \\
\hline 2009 & 0.52 & 1.05 & 0.39 & 1.96 \\
\hline 2010 & 0.63 & 0.84 & 0.52 & 1.99 \\
\hline 2011 & 0.51 & 0.98 & 0.53 & 2.02 \\
\hline 2012 & 0.38 & 1.29 & 0.36 & 2.02 \\
\hline 2013 & 0.42 & 1.22 & 0.36 & 1.99 \\
\hline 2014 & 0.37 & 1.34 & 0.33 & 2.04 \\
\hline 2015 & 0.24 & 1.44 & 0.29 & 1.97 \\
\hline 2016 & 0.60 & 1.41 & 0.36 & 2.36 \\
\hline All Sample & 0.48 & 1.20 & 0.40 & 2.05 \\
\hline \multicolumn{5}{|c|}{ Panel B: The Proportion of Components (\%) } \\
\hline 2007 & 29 & 64 & 23 & \\
\hline 2008 & 27 & 53 & 19 & \\
\hline 2009 & 27 & 54 & 20 & \\
\hline 2010 & 32 & 42 & 26 & \\
\hline 2011 & 25 & 49 & 26 & \\
\hline 2012 & 19 & 64 & 18 & \\
\hline 2013 & 21 & 61 & 18 & \\
\hline 2014 & 18 & 66 & 16 & \\
\hline 2015 & 12 & 73 & 15 & \\
\hline 2016 & 25 & 60 & 15 & \\
\hline All Sample & 23 & 58 & 19 & \\
\hline
\end{tabular}

Source : Prospectus 
TABLE III. Distribution OF GROSS SPREAD COMPONENTS By INDUSTRY

\begin{tabular}{|l|c|c|c|c|}
\hline & $\begin{array}{c}\text { Underwriting } \\
\text { Fee }\end{array}$ & $\begin{array}{c}\text { Management } \\
\text { Fee }\end{array}$ & $\begin{array}{c}\text { Selling } \\
\text { Fee }\end{array}$ & $\begin{array}{c}\text { Gross } \\
\text { Spread }\end{array}$ \\
\hline \multicolumn{5}{|l|}{ Panel A: The Level of Components (\%) } \\
\hline A & 0.42 & 0.97 & 0.39 & 1.79 \\
\hline M & 0.53 & 1.05 & 0.47 & 2.05 \\
\hline BIC & 0.34 & 1.33 & 0.31 & 1.98 \\
\hline MI & 0.34 & 2.31 & 0.43 & 2.19 \\
\hline CGI & 0.38 & 1.68 & 0.33 & 2.39 \\
\hline PRE & 0.57 & 0.97 & 0.43 & 1.98 \\
\hline IUT & 0.48 & 1.49 & 0.35 & 2.32 \\
\hline FIN & 0.37 & 1.09 & 0.33 & 1.78 \\
\hline TSI & 0.52 & 1.15 & 0.46 & 2.13 \\
\hline All Sample & 0.48 & 1.20 & 0.40 & 2.05 \\
\hline Panel B: The Proportion of Components (\%) & & \\
\hline A & 23 & 55 & 22 & \\
\hline M & 26 & 51 & 23 & \\
\hline BIC & 17 & 67 & 16 & \\
\hline MI & 11 & 75 & 14 & \\
\hline CGI & 16 & 70 & 14 & \\
\hline PRE & 29 & 49 & 22 & \\
\hline IUT & 21 & 64 & 15 & \\
\hline FIN & 21 & 61 & 18 & \\
\hline TSI & 24 & 54 & 22 & \\
\hline All Sample & 23 & 58 & 19 & \\
\hline
\end{tabular}

Source: Prospectus

Notes: $\mathrm{A}=$ Agriculture; $\mathrm{M}=\mathrm{Mining} ; \mathrm{BIC}=\mathrm{Basic}$ Industry and Chemicals; $\mathrm{MI}=$ Miscellaneous Industry; CGI=Consumer Goods Industry; PRE=Property and Real Estate; IUT=Infrastructure, Utilities and Transportation; FIN=Finance; TSI=Trade, Service and Investment.

The result of the components of gross spread shows that the level of each component was varied. The level of underwriting and selling fee relatively low which was less than $1 \%$, and the level of the management fee was almost twice as much fee as other. The level of underwriting fee ranged from $0.24 \%$ (2015) to $0.66 \%$ (2007), and the level of selling fee was between $0.29 \%$ (2015) and 0.52\% (2007 and 2010). The level of management was higher than other fees, and reached the highest spread level of $1.44 \%$ in 2015 . This makes the proportion of management fee as the biggest component. The highest proportion of management fee was at $73 \%$ in 2015 , while underwriting and selling fee for the same year was only $12 \%$ and $15 \%$, respectively.

The gross spread level of nine industries also varies from $1.78 \%$ to $2.39 \%$, as shown in panel A, Table 3 . The gross spread level of the finance industry was the lowest, and was the highest for the consumer goods industry. Four out of nine industries have lower gross spread level compared to the mean gross spread level of all samples. These are: agriculture $(1.79 \%)$, basic industry and chemicals $(1.98 \%)$, property and real estate $(1.98 \%)$, and finance industry $(1.78 \%)$. The underwriting fee of the industry sample was between $0.34 \%$ and $0.57 \%$, and only underwriters from three industries charged higher fees than the mean underwriting fee of all other industries. These are trade, service and investment, mining, and property and real estate, at $0.52 \%, 0.53 \%$ and $0.57 \%$ respectively. The table also indicates that basic industry and chemicals had the lowest selling fee $(0.31 \%)$, and mining industry had the highest $(0.47 \%)$. Further, it appears that management fees of all industries were higher than other fees. The fee was almost twice as much as the underwriting and selling fees for all industries. The proportion of gross spread component across industry can also be seen in panel B. This finding highlights that the eight industries spent from $50 \%$ to $75 \%$ of the gross spread for management fees. Only the property and real estate industry spent under $50 \%$, which was $49 \%$. Miscellaneous industry had the highest proportion of management fees at $75 \%$, followed by the consumer goods industry at $70 \%$.

\section{The Clustering PATtern OF Gross SPREAD}

This section examines the gross spread pattern in the Indonesian IPO market. Fig. 1 indicates the frequency of gross spread during 2007-2016. This shows that gross spread between $2 \%$ to $2.2 \%$ emerges as the most common spread of all IPOs in the sample with $16 \%$ of all IPOs. The next is between $2.4 \%$ to $2.6 \%$ (12\% of all IPO), followed by a gross spread from $3 \%$ to $3.2 \%$ (11\% of all IPO). These three groups of gross spread have the highest frequency. Data from this figure can be compared with the data in Table 4 which shows the frequency of gross spread by industry. In general, gross spread between $2 \%$ to $3 \%$ emerges as the most common spread, accounting for 78 IPOs or $43.57 \%$ of the sample. Meanwhile, gross spread between $1 \%$ and $2 \%$ emerges as the most common spread for basic industry and chemicals, and the finance industry.

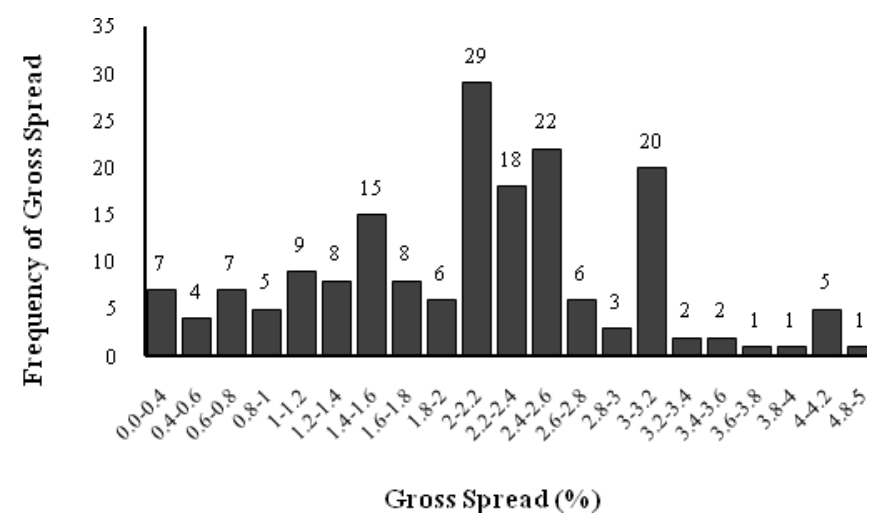

Source : Prospectus

Fig. 1. Frequency of Gross Spread 
TABLE IV. FREQUENCY OF GROSS SPREAD BY INDUSTRY

\begin{tabular}{|l|c|c|c|c|c|c|}
\hline \multirow{2}{*}{$\begin{array}{l}\text { Industry } \\
\text { Sectors }\end{array}$} & Mean & \multicolumn{5}{|c|}{ Gross Spread Level (\%) } \\
\cline { 3 - 7 } & Gross Spread & $\mathbf{0 - 1}$ & $\mathbf{1} \mathbf{- 2}$ & $\mathbf{2}-\mathbf{3}$ & $\mathbf{3}-\mathbf{4}$ & $\mathbf{4}<$ \\
\hline $\mathrm{A}$ & 1.79 & 3 & 1 & 6 & 1 & - \\
\hline $\mathrm{M}$ & 2.05 & 3 & 7 & 8 & 3 & 2 \\
\hline BIC & 1.98 & 1 & 5 & 2 & 2 & - \\
\hline MI & 2.19 & 1 & 1 & 3 & 2 & - \\
\hline CGI & 2.39 & 0 & 0 & 5 & 1 & - \\
\hline PRE & 1.98 & 2 & 12 & 15 & 1 & 1 \\
\hline IUT & 2.32 & 0 & 3 & 14 & 5 & - \\
\hline FIN & 1.78 & 6 & 10 & 5 & 4 & 1 \\
\hline TSI & 2.13 & 7 & 7 & 20 & 7 & 2 \\
\hline Total & & 23 & 46 & 78 & 26 & 6 \\
\hline
\end{tabular}

Source: Prospectus

Notes: $\mathrm{A}=$ Agriculture; $\mathrm{M}=$ Mining; $\mathrm{BIC}=\mathrm{Basic}$ Industry and Chemicals; $\mathrm{MI}=$ Miscellaneous Industry; CGI=Consumer Goods Industry; PRE=Property and Real Estate; IUT=Infrastructure, Utilities and Transportation; FIN=Finance; TSI=Trade, Service and Investment.

TABLE V. Gross SpRead CluStering PATtern

\begin{tabular}{|c|c|c|c|c|c|c|}
\hline & \multicolumn{2}{|c|}{ Mode Spread } & \multirow{2}{*}{$\begin{array}{c}\text { Three } \\
\text { Most } \\
\text { Common } \\
\text { Spread } \\
\text { Relative } \\
\text { Frequency }\end{array}$} & \multicolumn{3}{|c|}{$\begin{array}{c}\text { Gross Spread } \\
(\%)\end{array}$} \\
\hline & $\begin{array}{c}\text { Level } \\
(\%)\end{array}$ & $\begin{array}{c}\text { Relative } \\
\text { Frequency }\end{array}$ & & Mean & Median & $\begin{array}{c}\text { Std } \\
\text { Deviation }\end{array}$ \\
\hline $\begin{array}{c}\text { Gross } \\
\text { Spread }\end{array}$ & 2 & $13.9 \%$ & $36 . \%$ & 2.05 & 2 & 0.88 \\
\hline
\end{tabular}

Source : Prospectus

Table 5 presents the gross spread clustering pattern. The examination of clustering pattern uses two measurements: the mode gross spread and the relative frequency, which were used in [4]. The relative frequency is measured in percentages, as the number of IPOs with the mode gross spread is divided by the number of IPOs. In this study, this relative frequency is used as the measure of clustering. The table also shows the total percentage frequency of the three most common spreads. From the table, it can be seen that $2 \%$ emerges as the most common spread, accounted for $13 \%$ of all sample. The second most common spread was $2.5 \%(12 \%)$, followed by gross spread of $3 \%(11 \%)$. These spreads bring the total frequency of the three most common spreads up to $36 \%$ of IPO.

The gross spread of $2 \%$ shows as the mode spread or emerges as the common spread, however, gross spread did not show high clustering pattern at $2 \%$. The number of IPOs with gross spread level of $2 \%$ was only 25 issuers or $13.9 \%$ of all IPOs. The percentage was lower compared to the highest clustering patterns in other markets. For example, as mentioned in [4], the gross spread in the U.S. market was clustered in $7 \%$ accounting for $43 \%$. Meanwhile, in the Asia Pacific market, such as Hong Kong, India and Singapore, gross spread was clustered in $2.5 \%$, accounting for $94.8 \%$, $86 \%$ and $55.7 \%$, respectively. The European market also showed a high clustering pattern, such as Belgium at $66.7 \%$. Further, a weak clustering pattern in Indonesia can also be seen from the standard deviation of gross spread which was relatively high (0.88), compared to the U.S. standard deviation of only 0.0045 [6].

\section{DISCUSSION}

The evaluation of explicit cost of going public or gross spread revealed that the mean gross spread during sample period was $2.05 \%$. This spread level is lower compared to the $3.6 \%$ gross spread level of previous study using gross spread data from 1986 to 1999 [4]. The greatest cost incurred in explicit cost was the management fee at $58 \%$, following with $23 \%$ for underwriting fees, and $19 \%$ for selling fees. The result was consistent across years and industries.

The result suggests that the Indonesian underwriting market does not have an industry standard of 20/20/60 division fee, which are $20 \%$ management fee, $20 \%$ underwriting fee, and $60 \%$ selling concession, as the U.S does [6], [7]. The U.S. underwriting market focuses more on the selling fee to compensate underwriters, who may lead underwriters, co-managers, syndicate members, or nonunderwriters (selected dealers) in the selling group. Meanwhile, the Indonesian underwriting market has a greater focus on the management fee because of using book-building pricing strategy. Management fee enables underwriters to undertake marketing campaigns, assess market conditions, and organize road shows to obtain information and opinions from informed and potential investors prior to setting the offering price and IPO allocation.

The last result of evaluation of gross spread in the Indonesian market is the gross spread which did not show a high clustering pattern. Although $2 \%$ emerges as the common spread, the number of IPOs with a gross spread level of $2 \%$ was only $13 \%$ of all IPOs. Even though the sample of this study has been extended, the result is consistent with [4]. which examined gross spread of IPO from 1986-1999. The different between this research with the previous study is the gross spread of $3.50 \%$ emerges as the most common gross spread, accounted for $27.3 \%$ of 11 IPOs.

\section{CONCLUSION}

The aims of this study are to analyze the distribution of gross spread, and identify gross spread pattern. The Indonesian underwriting market has different fee setting practices which focus more on the management fee. Further, the result also shows that gross spread in Indonesian IPO did not show a high clustering pattern.

\section{REFERENCES}

[1] O.H. Ahn, J. Kim, and P. Son, "The pricing of underwriting services in the Korean IPO market: characteristics and determinants," Asia-Pacific Journal of Financial Studies, vol. 36, no. 5, pp. 731-764, 2007

[2] C.R. Chen, and N.J. Mohan, "Underwriter spread, underwriter reputation, and IPO underpricing: A simultaneous equation analysis,"Journal of Business Finance \& Accounting, vol. 29, no. 3-4, pp. 521-540, 2002.

[3] J.C. How, and J.J. Yeo, "The pricing of underwriting services in the Australian capital market," Pacific-Basin Finance Journal, vol. 8, no. 3, pp. 347-373, 2000. 
[4] S. Torstila, "The clustering of IPO gross spreads: International evidence,'Journal of Financial and Quantitative Analysis, vol. 38, no. 3, pp. 673-694, 2003.

[5] H.C. Chen, R.C. Fok, and Y.J. Wang, "Why do underwriters charge low underwriting fees for initial public offerings in Taiwan?"Journal of Business Finance \& Accounting, vol. 33, no. 7-8, pp. 979-1005, 2006.

[6] C. Lee, "Does the gross spread compensate lead underwriters for analyst coverage?"Accounting and Finance Research, vol. 1, no. 2, pp. 36-58, 2012.

[7] H.C. Chen,and J.R. Ritter, "The seven percent solution,"The Journal of Finance, vol. 55, no. 3, pp. 1105-1131, 2000. 